\title{
Calcium in the "soil-plant" system of apple orchard when using nitrogen and potash fertilizers
}

\author{
Elena Leonicheva ${ }^{1, *}$, Maxim Stolyarov ${ }^{2}$, Tatyana Roeva ${ }^{1}$, and Larisa Leonteva ${ }^{1}$ \\ ${ }^{1}$ Russian Research Institute of Fruit Crop Breeding (VNIISPK), Zhilina, Oryol district, Oryol region, \\ Russian Federation \\ ${ }^{2}$ Oryol State University named after I. S. Turgenev, Oryol, Russian Federation
}

\begin{abstract}
The experiment was carried out to study the relationship between the soil calcium conditions and the content of this element in fruit and leaves of apple trees at ground fertilization with nitrogen and potassium. The experimental orchard is located in the forest-steppe zone of the Central Russian Upland (Oryol region). The soil of the orchard is Loamy haplic luvisol with a slightly acidic reaction and a high content of organic matter. Fruit plantations are represented by apple trees of 'Sinap orlovsky' variety on rootstock 54-118 planted in 2013. Ammonium nitrate and potassium chloride were used as soil fertilizers and applied early in spring at doses of N30K40, N60K80 and N90K120. Annually from 2016 to 2019, the content of exchangeable and water-soluble Ca compounds in the orchard soil and the total element content in leaves and fruits were determined. With the annual application of nitrogen and potash fertilizers the changes in the conditions of apple tree calcium nutrition occured already in the first years after treatments. The changes lay in increasing the calcium mobility and subsequent decrease in the element's concentration in the root zone. At the same time, there was an annual decrease in the calcium status of fruits. The $\mathrm{Ca}$ content in fruits was positively correlated with the content in the soil of exchange $(r=0.43 ; \mathrm{P}<0.05)$ and water-soluble $(r=0.51 ; \mathrm{P}<0.01)$ forms of the element. There was no statistically significant relationship between the studied soil calcium forms and element content in apple leaves.
\end{abstract}

\section{Introduction}

The role of calcium nutrition in ensuring the quality of apple fruit is well known. Physiological disorders associated with calcium deficiency, such as bitter pits, vitrescence, pulp decomposition, etc., are the cause of apple producers' losses in all regions growing this crop $[1,2,3,4]$.

For apple trees, the main source of calcium is soil. The use of calcium-containing fertilizers in apple orchards gives positive results on acidic soils [2]. However, physiological

\footnotetext{
* Corresponding author: leon.elena@list.ru
} 
disorders associated with a lack of calcium are often observed in fruits grown on calcareous soils $[4,6]$.

It is known that a significant influence on the fruits' calcium status is exerted by the regime of mineral nutrition, including the use of nitrogen and potassium fertilizers $[2,7,8]$, but the effect of specific fertilizers types, the terms and methods of their application are not clearly defined.

The analysis of publications reflecting apple trees nutrition problems with calcium shows the lack of system studies that simultaneously consider the state of calcium in the plant and the connection of the plant organism with the environment.

The purpose of this study was to investigate the relationship between the soil calcium conditions and the content of this element in fruit and leaves of apple trees at application of nitrogen and potassium fertilizers.

\section{Materials and methods}

Research was carried out in 2016-2019 in the medium-grown apple orchard planted in 2013 located in the orchard area of Russian Research Institute of Fruit Crop Breeding (Oryol region). The trees allocation scheme was $6 \times 3 \mathrm{~m}$. 'Sinap orlovsky' variety of apple trees on semi-dwarf rootstock 54-118 was chosen for research. The variety was zoned in the regions of the North-Western, Mid-Volga, Central and Central Chernozem regions of the Russian Federation. The variety has a long storage life, but with a lack of calcium, the fruits can be damaged by bitter pits [9].

The soil of the experimental site was loamy haplic luvisol, underlain by dolomite limestones. The soil had the following agrochemical parameters in the $0 \ldots 20 \mathrm{~cm}$ layer: $\mathrm{pH}_{\mathrm{KCl}}$ $=5.4$, organic matter content $-2.15 \%$, alkaline hydrolyzed nitrogen content $-98.70 \mathrm{mg} / \mathrm{kg}$, labile phosphorus - $134.44 \mathrm{mg} / \mathrm{kg}$, exchange potassium - $97.88 \mathrm{mg} / \mathrm{kg}$. The content of calcium and magnesium exchange compounds in the soil was high: 14.98 and $4.39 \mathrm{mmol} / 100$ g respectively. The soil management system: in the rows of trees - treatments by herbicides, but in the interrows the grass was mowed.

Field experiment in studying mineral fertilizers' efficiency started in 2015. Experimental treatments: 1. Control (no fertilizer); 2. N30K40; 3. N60K80; 4. N90K120. Nitrogen and potash fertilizers in the form of granular $\mathrm{NH}_{4} \mathrm{NO}_{3}$ and $\mathrm{KCl}$ were applied every spring to a 10 $15 \mathrm{~cm}$ depth. The experiment was carried out in fourfold repetition with 5 trees per record plot.

Every year, soil samples were collected in the sub-crown tree zone at $1.0 \ldots 1.5 \mathrm{~m}$ distance from the trunk at a depth of $0 \ldots 20 \mathrm{~cm}$, in which the content of exchange and water-soluble calcium compounds was determined. Exchange calcium was extracted by $1.0 \mathrm{M} \mathrm{NaCl}$ solution at a 1:20 soil:solution ratio. The 1:5 soil:water ratio was used to extract water-soluble forms of calcium [10].

Leaf samples were collected in the last decade of July from the middle part of annual shoots, fruit samples - in the phase of picking maturity. Plant samples were ashed in a muffle furnace at $450^{\circ} \mathrm{C}$, ash was dissolved in $20 \% \mathrm{HCl}$. Determination of calcium in ash solution and soil extracts was carried out by a complexonometric method using complexing agent III $($ Edta-NA $)$ [10].

The accounting of the fruit harvest was carried out in 2017, 2018 and 2019 by weight method considering fruits' weight from each experimental tree.

For statistical data processing, two-factor dispersion analysis was used with the estimation of the differences' significance based on the Fisher and LCD criterion at the level of significance $\mathrm{P}=0.05$ and $\mathrm{P}=0.01$ [11]. 


\section{Results and Discussion}

Research was carried out in an apple orchard entering fruiting. In 2016, young trees have not yet yielded a commercial harvest. A few fruits obtained in 2016 were used to determine their mineral composition. In the following years on experimental average, the yield of Sinap orlovsky variety was $2,72 \pm 0,62,10,96 \pm 1,51$ and 9,62 $\pm 4,33 \mathrm{~kg} /$ tree in 2017,2018 and 2019 respectively. The application of nitrogen and potash fertilizers had no statistically significant effect on tree productivity (Figure 1).

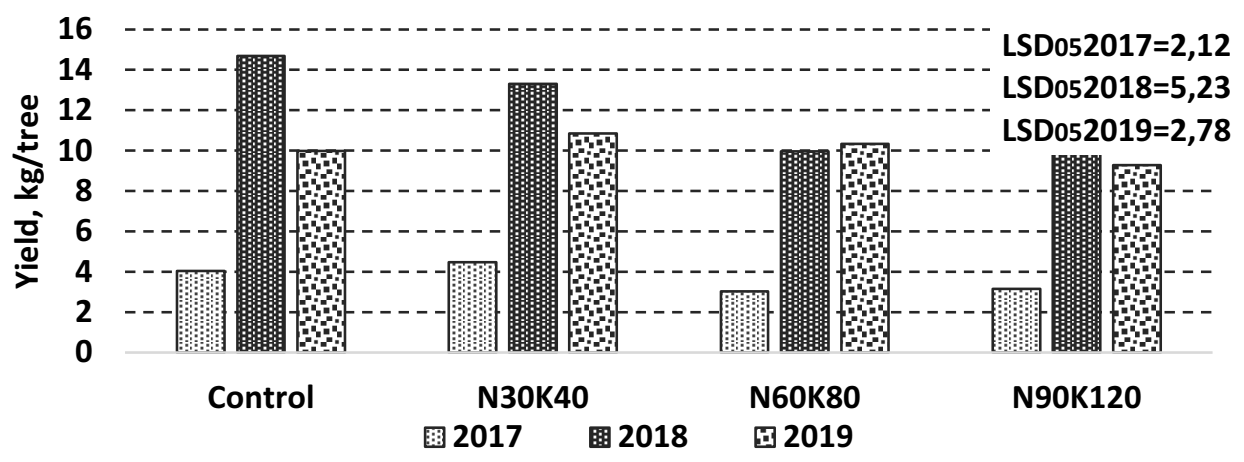

Fig. 1. Productivity of apple trees of 'Sinap orlovsky' variety, 2017-2019 (kg/tree)

The quantity and ratio of exchange and water-soluble calcium compounds in the experimental orchard's soil depended both on nitrogen and potassium fertilizers introduced into the soil and on weather conditions of the growing season. Temperature conditions in the years of research were similar and close to the long-term average, with the exception of the colder spring of 2017. As shown in Table 1, the differences in total rainfall are more noticeable.

Table 1. The amount of precipitation $(\mathrm{mm})$ during the research period

\begin{tabular}{|r|c|c|c|c|}
\hline \multirow{2}{*}{ Months } & \multicolumn{4}{|c|}{ Years } \\
\cline { 2 - 5 } & $2015-2016$ & $2016-2017$ & $2017-2018$ & $2018-2019$ \\
\hline October-March & 242.4 & 181.1 & 294.7 & 207.1 \\
\hline & 2016 & 2017 & 2018 & 2019 \\
\hline April-September & 283.1 & 361.0 & 243.4 & 287.7 \\
\hline$\Sigma$ & 525.5 & 542.1 & 538.1 & 494.8 \\
\hline
\end{tabular}

It is known that the amount of precipitation is one of the main factors that determine the calcium loss from the soil due to leaching $[12,13]$. For loamy soils, it is shown that $3 / 4$ of the annual calcium loss occurs between October and March [13]. In the studied soil, the lowest level of exchange calcium was noted in 2017 with the highest total precipitation amount during the growing season. The lowest content of water-soluble element forms was noted in 2018 after the winter with the most abundant precipitation (Table 2).

Table 2. Dynamics of exchange and water-soluble calcium forms in field experiment's soil with nitrogen and potassium fertilizers' application, 2016 - 2019

\begin{tabular}{|l|c|c|c|c|c|}
\hline \multirow{2}{*}{ Factor A (treatments) } & \multicolumn{3}{|c|}{ Factor B (years of research) } & \multirow{2}{*}{$\begin{array}{c}\text { Average } \\
\text { A }\end{array}$} \\
\cline { 2 - 5 } & 2016 & 2017 & 2018 & 2019 & \\
\hline \multicolumn{5}{|c}{ Water soluble Ca, mmol/100 g } \\
\hline Control (no fertilizer) & 0.78 & 0.48 & 0.17 & 0.49 & 0.47 \\
\hline N30K40 & $1.57^{* *}$ & 0.30 & 0.20 & 0.59 & $0.66^{*}$ \\
\hline N60K80 & $1.53^{* *}$ & 0.38 & 0.20 & 0.78 & $0.72^{* *}$ \\
\hline N90K120 & $2.54^{* *}$ & 0.61 & 0.26 & 0.68 & $1.02^{* *}$ \\
\hline
\end{tabular}




\begin{tabular}{|c|c|c|c|c|c|}
\hline Average B & 1.61 & 0.43 & 0.21 & 0.64 & \\
\hline \multicolumn{6}{|c|}{$\begin{aligned} \mathrm{LCD}_{05} \mathrm{~A} & =0.18 \mathrm{LCD}_{05} \mathrm{~B}=0.18 \mathrm{LCD}_{05} \mathrm{AB}=0.37 \\
\mathrm{LCD}_{01} \mathrm{~A} & =0.24 \operatorname{LCD}_{01} \mathrm{~B}=0.24 \operatorname{LCD}_{01} \mathrm{AB}=0.48\end{aligned}$} \\
\hline \multicolumn{6}{|c|}{ Exchange $\mathrm{Ca}, \mathrm{mmol} / 100 \mathrm{~g}$} \\
\hline Control (no fertilizer) & 15.65 & 15.58 & 15.67 & 15.88 & 15.69 \\
\hline N30K40 & 15.87 & $14.99^{* *}$ & 15.70 & 15.87 & 15.61 \\
\hline N60K80 & $15.12 *$ & $14.88 * *$ & $14.99 * *$ & $14.84 * *$ & $14.96^{* *}$ \\
\hline N90K120 & 15.50 & $14.95^{* *}$ & $15.09 * *$ & $14.81 * *$ & $15.08^{* *}$ \\
\hline Average B & 15.53 & 15.10 & 15.36 & 15.35 & \\
\hline \multicolumn{6}{|c|}{$\begin{array}{l}\mathrm{LCD}_{05} \mathrm{~A}=0.20 \mathrm{LCD}_{05} \mathrm{~B}=0.20 \mathrm{LCD}_{05} \mathrm{AB}=0.40 \\
\mathrm{LCD}_{01} \mathrm{~A}=0.26 \mathrm{LCD}_{01} \mathrm{~B}=0.26 \mathrm{LCD}_{01} \mathrm{AB}=0.53\end{array}$} \\
\hline
\end{tabular}

* differences with control are reliable at 5\% significance level

$* *$ differences with control are reliable at $1 \%$ significance level

In the second year from the start of nitrogen and potassium fertilizers' application to the soil (2016), a reliable increase in the concentration of water-soluble calcium compounds was established in the soil of fertilized plots (Table 2). In 2017 and 2018, the concentration of water-soluble calcium in the orchard's soil decreased by $4 \ldots 8$ times compared to the level of 2016. This decrease can be explained by the washing of water-soluble calcium compounds in the excessively moistening summer period of 2017, followed by the snowy winter of 2017... 2018. In treatments with fertilizers, the reduction in the level of water-soluble calcium in these years was more pronounced than in the control (Table 2). In 2019, the soil of fertilized plots showed a statistically significant increase in the concentration of watersoluble calcium compared to the level of 2018, while on the control the indicator's value of these years did not reliably differ.

On average, over 4 years of research in all treatments, the content of water-soluble element forms in the soil layer of $0 \ldots 20 \mathrm{~cm}$ was significantly higher than control (Table 2).

The exchange calcium content in the soil of control plots was at a high level during 4 vegetation periods. Fertilizer application contributed to the decrease of this indicator (Table 2). The most stable effect was in the treatment with $\mathrm{N} 60 \mathrm{~K} 80$, where a reliably lower element exchange forms concentration was observed annually in the soil. When fertilizing with the smallest of the used doses N30K40, a statistically significant decrease in the level of exchange calcium was observed only in the wettest year of 2017.

Leaf diagnostics is a widely used method for assessing the mineral nutrition conditions of fruit crops. According to literary data, the optimal level of calcium content in apple leaves is $1.3 \ldots 2 \%$ dry weight [7]. Analysis of calcium concentration in the leaves of 'Sinap orlovsky' showed that during the first three years $(2016 \ldots$ 2018) the leaves contained an insufficient amount of this element, and only in 2019 calcium levels in the leaves were above $1.3 \%$ in all experimental options (Table 3). The lowest values of the parameter were in 2017 with the lowest level of exchange calcium in the soil.

Table 3. Calcium content in fruit and apple leaves of the 'Sinap orlovsky' variety, 2016 - 2019

\begin{tabular}{|c|c|c|c|c|c|}
\hline \multirow{2}{*}{ Factor A (treatments) } & \multicolumn{3}{|c|}{ Factor B (years of research) } & Average \\
\cline { 2 - 5 } & 2016 & 2017 & 2018 & 2019 & A \\
\hline \multicolumn{7}{|c|}{ The content of Ca in leaves, \% DW } \\
\hline Control (no fertilizer) & 1.01 & 0.94 & 1.03 & 1.37 & 1.09 \\
\hline N30K40 & 1.03 & 0.92 & 1.02 & 1.42 & 1.10 \\
\hline N60K80 & 1.01 & 0.90 & 1.00 & 1.38 & 1.07 \\
\hline N90K120 & 1.04 & 0.90 & 1.02 & 1.38 & 1.09 \\
\hline Average B B by A F $<\mathrm{F}_{t} \mathrm{LCD}_{05} \mathrm{~B}=0.03$ & by AB Ff $<\mathrm{F}_{\mathrm{t}}$ \\
\hline \multicolumn{7}{|c|}{$\mathrm{Ca}$ content in fruit, $\mathrm{mg} / 100 \mathrm{~g} \mathrm{FW}$} \\
\hline
\end{tabular}




\begin{tabular}{|l|c|c|c|c|c|}
\hline Control (no fertilizer) & 9.64 & 8.92 & 8.36 & 8.16 & 8.77 \\
\hline N30K40 & 9.44 & 9.72 & 8.32 & 7.88 & 8.84 \\
\hline N60K80 & $11.30^{*}$ & 9.60 & $7.08^{*}$ & $6.36^{*}$ & 8.84 \\
\hline N90K120 & 10.40 & 9.00 & $7.08^{*}$ & $7.16^{*}$ & 8.46 \\
\hline Average B & 10.19 & 9.31 & 7.71 & 7.39 & \\
\hline \multicolumn{6}{|c|}{ LCD $_{05} \mathrm{~A}=0.49$ LCD $_{05} \mathrm{~B}=0.49 \mathrm{LCD}_{05} \mathrm{AB}=0.98$} \\
\hline
\end{tabular}

* differences with control are reliable at 5\% significance level

For apple orchards grown in soil-climatic conditions of Central Russia, a negative correlation between potassium fertilizers' doses and calcium content in leaves is shown [8]. In our experiment, the annual application of increasing doses of $\mathrm{NH}_{4} \mathrm{NO}_{3}$ and $\mathrm{KCl}$ into the soil did not significantly affect the calcium status of the leaves (Table 3 ).

The calcium content of apple fruit grown in the same orchard can vary significantly in different vegetation periods $[4,6,14]$. During four years of research, there was an annual decrease in calcium concentration in apples (Table 3). This can be due to both changes in calcium nutrition conditions, as well as trees' growth and increased fruit load. Nitrogen and potash fertilizers had a significant effect on the calcium content in the fruits of 'Sinap orlovsky' variety in 2016, 2018 and 2019.

According to various researchers, apples should contain at least $5 \ldots 14 \mathrm{mg}$ of calcium per $100 \mathrm{~g}$ of fresh weight so as not to be affected by bitter pits $[2,15,16]$. The first fruits of 'Sinap orlovsky' obtained in 2016 on the third year after orchard planting at the highest level of soil calcium contained calcium in the amount of $10.19 \pm 0.83 \mathrm{mg} / 100 \mathrm{~g} \mathrm{FW}$ (experimental average). Under these conditions, a significant increase in the calcium level in apples was noted in the treatment with N60K80. In the following years, with a gradual annual decrease in the calcium status of fruits, the use of soil fertilizers contributed to an additional decrease in the indicator. The negative effect of soil fertilizers on the fruits' calcium uptake can be associated with the deterioration of the plants' calcium nutrition conditions as a result of reducing the concentration of available calcium forms in the soil (shown in table 2), and due to antagonism between potassium, ammonium and calcium cations in the processes of root uptake.

With the help of correlation analysis, the dependencies' search between the level of exchangeable and water-soluble calcium forms in the soil and the concentration of the element in apple leaves and fruits was performed. The content of exchange calcium forms in the soil is an indicator traditionally used in Russia to assess the soil supply with compounds of this element which available for crops. A reliable positive correlation was established between the calcium status of fruits and the exchange calcium content in the $0 \ldots 20 \mathrm{~cm}$ soil layer $(r=0.43 ; \mathrm{P}<0.05)$. The concentration of water-soluble calcium in the soil of the orchard was also correlated with the element content in the fruit, and the connection was reliable at a higher significance level $(\mathrm{r}=0.51 ; \mathrm{P}<0.01)$. At the same time, there were no statistically significant relationships between the studied forms of soil calcium and calcium content in apple leaves, as well as between the content of the element in fruits and leaves.

Thus, the relationship analysis between the state of calcium in the soil and its concentration in vegetative organs and fruits showed that the determination of the content of water-soluble and exchange calcium forms in the soil can be a promising diagnostic technique for prognosis of calcium status of fruits. At the same time, the absence of a significant correlation between calcium content in fruits and leaves indicates insufficient informativeness of leaf diagnostics.

\section{Conclusion}

As a result of conducted studies, it was established that with the annual application of nitrogen and potash fertilizers in the form of $\mathrm{NH}_{4} \mathrm{NO}_{3}$ and $\mathrm{KCl}$ to loamy haplic luvisol of 
apple orchard, changes in the conditions of apple trees' calcium nutrition occur already in the first years after fertilizer use, which lies in increasing the calcium mobility and subsequent decrease in the element's concentration in the root layer. Since fertilizers did not increase the yield of Sinap orlovsky variety and at the same time negatively affected the calcium status of fruits, in order to maintain a stable calcium condition of loamy haplic luvisols, the use of these fertilizers in young gardens when cultivating varieties sensitive to calcium deficiency should be minimized.

The research of correlations between the level of available calcium in the soil and its concentration in apple leaves and fruits using a 4-year data array showed that the concentration of exchange and water-soluble element compounds in the root zone should be considered when predicting calcium levels in apples and planning the use of calciumcontaining fertilizers.

\section{Acknowledgments}

The reported study was funded by RFBR, project number 19-316-90016/19.

\section{References}

1. P.J. White, M.R. Broadley, Annals of Botany, 92. 487-511 (2003) doi:10.1093/aob/mcg164, available online at www.aob.oupjournals.org

2. T. Jemrić, I. Fruk, M. Fruk, S.Radman, L. Sinkovič, G. Fruk, Spanish Journal of Agricultural Research, 14 (4), e08R01 (2016) http://dx.doi.org/10.5424/sjar/20161448491

3. A.I. Kuzin, A.S. Ilinskiy, Yu.V. Trunov, Pomiculture \& Small Fruits Culture in Russia. 52, 112-119, (2018) DOI: 10.31676/2073-4948-2018-52-112-119

4. E. Torres, I. Recasens, J. Lordan and S. Alegre, Sci. Hort. 217, 65-89 (2017) https://dx.doi.org/10.1016/j.scienta.2017.01.028

5. A.R. Biggs, G.M. Peck, HortTechnology, 25(3), 385-391 https://doi.org/10.21273/HORTTECH.25.3.385

6. E.V. Leonicheva, T.A. Roeva, L.I. Leonteva, M.E. Stolyarov, M.A. Makarkina, Hort, Vitic. 5, 49-57, (2018) https://doi.org/10.31676/0235-2591-2018-5-49-57

7. C. Watkins, J. Schupp, D. Rosenberger, New York Fruit Quarterly, 12(2),15-21 (2004) URL: http://nyshs.org/wp-content/uploads/2016/10/Calcium-Nutrition-and-Control-ofCalcium-related-Disorders.pdf

8. A.I. Kuzin, N.Ya. Kashirskaya, A.M. Kochkina, A.V. Kushner, Plants, 9(10), 1366 (2020) https://doi.org/10.3390/plants9101366

9. M. Makarkina, A. Nikitin, Fruit Growing and Viticulture of South Russia, 7(1), 177-126 (2011) URL: http://www.journalkubansad.ru/pdf/11/01/12.pdf

10. V.G. Mineev, V.G. Sychev, O.A. Amelyanchik, T.N. Bolsheva, N.F. Gomonova, E.P. Durynina, V.S. Egorov, E.V. Egorova, N.L. Edemskaya, E.A. Karpova, et al. Educational Aid on Agricultural Chemistry, 2nd ed.; Publishing House of Lomonosov Moscow State University 83-86, 355-357 (2001) (In Russian)

11. B.A. Dospekhov, A Field Experiment Method, 1-351 (1985)

12. M. Egli, P. Fitze, Catena, 46(1), 35-62 (2001) https://doi.org/10.1016/S03418162(01)00154-0 
13. N.I. Akanova, I.A. Shilnikov, S.Yu. Efremova, M.S. Avakov, Problems of Agrochemistry and Ecology, 1, 28-35 (2017)

14. I.A. Sidorova, E.S. Salina, N.S. Levgerova, Sovremennoe sadovodstvo - Contemporary horticulture, 3, 27-32 (2016) URL: http://journal.vniispk.ru/pdf/2016/3/34.pdf

15. V.A. Gudkovski, L.V. Kuznetsova, N.P. Ponomariova, Acta Hort. (ISHS), 274, 175-177 (1990) DOI:10.17660/ActaHortic.1990.274.18.

16. T.G. Prichko, M.G. Germanova, N.V. Droficheva, Russian Federation Parent No 2593347, Moscow: Federal Institute of Industrial Property (2015) 